\title{
STUDIES OF SYPHILITIC ANTIBODIES*† II. SUBSTANCES RESPONSIBLE FOR BIOLOGICAL FALSE POSITIVE SERO-REACTIONS
}

\author{
BY \\ K. AHO \\ State Serum Institute, Helsinki, Finland
}

It has been generally assumed that the substances responsible for biological false positive (BFP) seroreactions for syphilis are antibodies of the same kind as the syphilitic anti-lipoidal antibodies. However, the available evidence for this view is meagre and mainly circumstantial. It has been observed that in the VDRL test substitution of the cardiolipin in the antigen by certain surface-active substances results in a test system which has nothing to do with syphilis but gives results parallel to those in the tests for C-reactive protein (Tuomioja and Kajanne, 1956; Salo and Tuomioja, 1958). Therefore, every substance reacting with heart extracts need not necessarily be an antibody.

Except in the case of transient reactions, it is impossible to decide on clinical grounds alone whether the reactions are false positives or whether they mark a latent syphilitic infection. By using a battery of tests it is sometimes possible to draw certain conclusions. Thus, sera reactive with crude alcoholic heart extracts but non-reactive with purified cardiolipin antigens are frequently falsely positive (Olansky, Harris, and Hill, 1953; Löffler, 1959). The introduction of the TPI test formed a rational basis for the study of the persistent BFP reactions. However, there are many cases of old untreated syphilis that are non-reactive in the TPI test, and a considerable proportion of cases thought to be persistent BFP reactors based on a non-reactive TPI test have been positive in the FTA-ABS test (Tuffanelli, Wuepper, Bradford, and Wood, 1967; Lassus, Mustakallio, Aho, and Putkonen, 1967). An additional difficulty in the characterization of substances responsible for the BFP reactions is that their serum titres are usually low.

The present report deals with immunochemical and serological properties of anti-lipoidal substances in selected relatively high-titred sera from patients with no clinical or anamnestic evidence of syphilis and with completely negative TPI and FTA-ABS

\footnotetext{
* Supported by a grant from the Sigrid Jusélius Foundation, Finland.

tReceived for publication July 14, 1967
}

tests. Evidence is sought for association of the substances with the immunoglobulins, and an attempt is made to correlate the serological reaction pattern with the behaviour of the substances in fractionation procedures.

\section{BFP-Sera \\ Material and Methods}

Four sera came from persons with false positive reactions after small-pox vaccination (Salo, Somer, Aho, and Cantell, 1966). Their VDRL titres ranged from 4 to 8.

Four sera came from patients with transient BFP reactions associated with ornithosis. They all were negative in the VDRL test and their Kahn titres ranged from 8 to 16.

Four sera came from patients with transient BFP reactions picked up because of their high titres or peculiar type of reaction pattern.

Twelve sera (those with the highest titres) came from patients included in a series of 51 persistent BFP reactors (Lassus and others, 1967). In the majority of these sera the reactions resembled those seen in syphilis. The highest VDRL titre in this group was 32.

The remaining six sera came from patients with persistent BFP reactions found among 5,000 serum samples sent for treponemal tests in 1961-66. These sera were selected because of their high titres or peculiar type of reaction patterns.

The fractionations and the serological tests were performed as described in the Part I of this paper (Aho, 1967a). In the fractionation experiments with DEAEcellulose chromatography, use was made of mononucleosis agglutinins against horse erythrocytes as an indicator of $\gamma \mathrm{M}$ globulin. For this purpose the mononucleosis serum was first absorbed with papain-treated horse erythrocytes to remove the normal $\gamma \mathrm{G}$ heteroagglutinins (Aho, 1967b).

\section{Results}

\section{Serological Properties of the Sera}

Based on their serological reaction patterns, the BFP sera included in the study could be divided into five groups:

(a) One serum from a patient with transient reactions had a Kahn titre of 64 but was completely negative in all other tests. 
(b) Four sera were positive in the Kahn test (the titres ranged from 8 to 16) and they fixed complement with crude alcoholic heart extracts, but were completely negative in the VDRL test and did not fix complement with cardiolipin antigen in the Kolmer test. All these sera were strongly positive in the complement-fixation test for ornithosis, and the patients were suffering from broncho-pulmonary infections.

(c) Four sera were positive in the Kahn test and fixed complement with crude alchoholic heart extracts. Although they were completely negative in the VDRL test they were positive in the Kolmer test. It appeared that these sera did not fix complement with the VDRL antigen and the optimum dilution of the Kolmer antigen was different from that used in testing syphilitic sera. Table I shows the reactions of this type of sera with varying dilutions of the Kolmer antigen. There was a fifth serum included in the group that was negative in the Kahn test but reacted with the Kolmer antigen in the same manner as the four other sera of this group. Two of the five sera came from patients with persistent BFP reactions. One of these (K.V.) had strongly positive reactions; the Kahn titre was 512 .

(d) Four sera were positive in the VDRL test but reacted better with the crude alcoholic heart extracts and with the Kolmer antigen. The reaction

TABLE I

REACTIVITY OF FOUR BFP SERA WITH VARYING DILUTIONS OF KOLMER ANTIGEN

\begin{tabular}{l|ccc}
\hline \multirow{2}{*}{ Serum } & \multicolumn{3}{|c}{$\begin{array}{c}\text { Titre of Serum with } \\
\text { Kolmer Antigen Diluted }\end{array}$} \\
\cline { 2 - 4 } & $1 / 37 \cdot 5$ & $1 / 150$ & $1 / 600$ \\
\hline H.A. Transient BFP & 128 & 8 & $<4$ \\
M.K. Transient BFP & 64 & 32 & $<4$ \\
P.P. Persistent BFP & 256 & 32 & 16 \\
R.N. Syphilitic & 32 & 64 & 64 \\
\hline
\end{tabular}

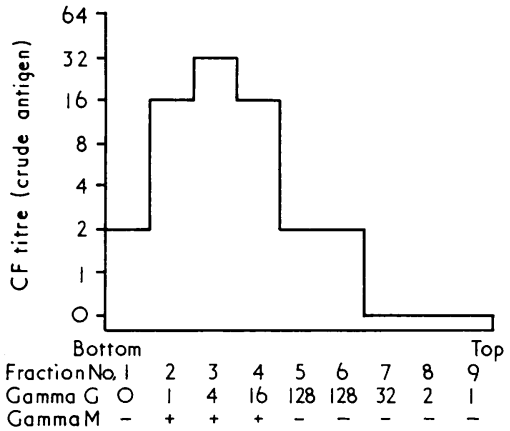

FIG. 1a.-Ultracentrifugation of serum H.K. (ornithosis). Serological activity is located predominantly in the $19 \mathrm{~S}$ fraction. pattern with varying dilutions of the Kolmer antigen resembled that of the sera belonging to the previous group, although the titre differences were not so pronounced. All the four sera came from patients with persistent BFP reactions. One of these (A.R.) had strongly positive reactions; the VDRL titre was 8 , but the Kolmer titre was 1024 (corresponding to 256 times the starting dilution of the serum).

(e) The remaining sixteen sera had serological reactions resembling those seen in syphilis, i.e. they reacted slightly better with the cardiolipin antigens than with the crude extracts. Four came from persons with transient BFP reactions associated with small-pox vaccination and the remaining twelve from persistent BFP reactors. Two of the patients had systemic lupus erythematosus.

\section{Ultracentrifugation Experiments}

All the BFP sera included in the study were fractionated by density gradient ultracentrifugation. The fractions were tested for immunoglobulins in the same manner as the syphilitic sera. 25 sera were positive in the Kolmer complement-fixation test. In these cases the fractions were tested with this system. Four sera (those from the patients with ornithosis) were tested with the complementfixation system utilizing cholesterol-sensitized heart extracts as an antigen. One serum from a patient with transient reactions was positive in the Kahn test (titre 64) but not in any other test system. In this instance the fractions were tested only by the Kahn test. In all the sera there were at least three reactive tubes in the fractions with the highest titres.

Fig. 1 illustrates two elution diagrams that differed from those seen in syphilitic sera. In Fig. $1 a$ (H.K.) the serological activity is mainly in the $19 \mathrm{~S}$ fraction, but there is a small amount of activity also in the 7S fraction (ornithosis of long duration). It is possible that the latter material is slightly heavier than the $7 \mathrm{~S}$ $\gamma \mathrm{G}$ globulin.

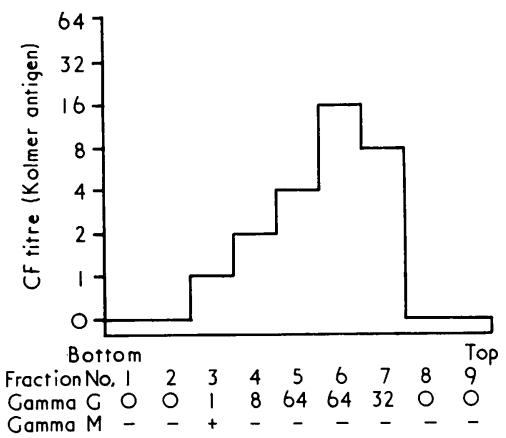

FIg. 1b.-Ultracentrifugation of serum P.P. (malignant lymphoma). Serological activity is located predominantly in the $7 \mathrm{~S}$ fraction. 
In Fig. $1 b$ (P.P.) the serological activity is located mainly in the 7S fraction, but there is a small amount of activity also in the heavier fractions (malignant lymphoma).

Of the twelve sera with transient reactions, serological activity was located solely in the $19 \mathrm{~S}$ fraction in eight instances. The four sera from persons with small-pox vaccination fitted this pattern of reactivity. In two sera the activity was mainly in the 19S fraction, but there was slight activity also in the $7 \mathrm{~S}$ fraction. In the remaining two sera (one of them was positive only in the Kahn test) the serological activity was located roughly in the $7 \mathrm{~S}$ fraction. However, the activity peak did not correspond exactly to the peak of 7S $\gamma \mathrm{G}$ globulin, but appeared slightly earlier; i.e. the substances may have been heavier than the $\gamma \mathrm{G}$ globulin. The ultracentrifugations were repeated with similar results. No serum was available for further characterization of the substances.

Of the eighteen sera with chronic BFP reactions, serological activity was located solely in the $19 \mathrm{~S}$ fraction in ten instances. In the other sera activity was found in both the $19 S$ and $7 S$ fractions. In three sera the activity was predominantly in the $19 \mathrm{~S}$ fraction and in one predominantly in the 7S fraction (Fig. 1b). In four sera the titres were about the same in both fractions. These four sera had syphilitic type serological reactions.

In one serum (from patient A.R. in Table II) with the serological activity mainly in the $19 \mathrm{~S}$ fraction and a relatively small component in the $7 \mathrm{~S}$ fraction, the serum titres were very high. Recentrifugation experiments were made with the lighter component and these indicated that the serologically active material had intermediate sedimenting properties rather than those of $7 \mathrm{~S} \gamma \mathrm{G}$ globulin.

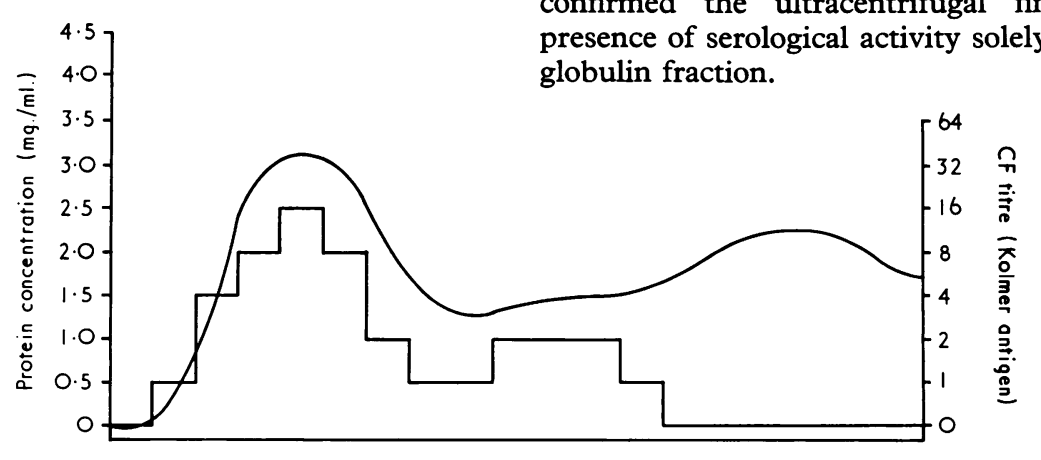

\begin{tabular}{|c|c|c|c|c|c|c|c|c|c|c|c|c|c|c|c|c|c|c|}
\hline $\begin{array}{l}\text { Fraction } \mathrm{Na} .1 \\
\text { Gamma G O } \\
\text { Gamma M O } \\
\text { Gamma A O }\end{array}$ & 0 & $\begin{array}{l}3 \\
0 \\
2 \\
0\end{array}$ & 1 & $\begin{array}{l}5 \\
1 \\
8 \\
1\end{array}$ & 1 & $\begin{array}{l}7 \\
0 \\
1 \\
0\end{array}$ & 0 & $\begin{array}{l}9 \\
0 \\
0 \\
2\end{array}$ & 0 & $\begin{array}{l}11 \\
0 \\
0 \\
8\end{array}$ & 2 & $\begin{array}{l}13 \\
16 \\
0 \\
4\end{array}$ & 32 & $\begin{array}{l}15 \\
32 \\
0 \\
1\end{array}$ & 32 & $\begin{array}{l}17 \\
16\end{array}$ & 8 & \\
\hline
\end{tabular}

FIG. 2.-Gel filtration (Sephadex G-200) of serum A.R. Serological activity is located predominantly in the $\gamma M$ globulin fraction but there is a small separate component in the intermediate fractions between the peaks of $\gamma \mathrm{M}$ and $\gamma \mathrm{G}$ globulin. Curve: Protein concentration in effluents.

TABLE II

DEAE-CELLULOSE CHROMATOGRAPHY OF FOUR BFP SERA

\begin{tabular}{|c|c|c|c|c|}
\hline \multirow{3}{*}{ Elution System } & \multicolumn{4}{|c|}{ Titre with Kolmer Antigen } \\
\hline & T.L.* & E.Z.* & A.R.* & P.P.t \\
\hline & $19 \mathrm{~S} \approx 7 \mathrm{~S}$ & $\begin{array}{l}\text { In } 19 S \\
\text { Only }\end{array}$ & $19 S \gg 7 S$ & $19 S \ll 7 S$ \\
\hline $\begin{array}{l}0.02 \mathrm{M} \text { phosphate buffer, } \\
\text { pH } 7.2\end{array}$ & 8 & $<1$ & $<1$ & $<1$ \\
\hline $\begin{array}{l}0.02 \mathrm{M} \text { phosphate buffer, } \\
\text { pH } 7 \cdot 2 \text {, in } 0 \cdot 15 \mathrm{M} \\
\text { sodium chloride }\end{array}$ & 2 & $<1$ & 2 & $<1$ \\
\hline $\begin{array}{l}0.02 \mathrm{M} \text { phosphate buffer, } \\
\text { pH } 7.2 \text {, in } 0.3 \mathrm{M} \\
\text { sodium chloride }\end{array}$ & 8 & 64 & 128 & $<1$ \\
\hline $\begin{array}{l}0.02 \mathrm{M} \text { phosphate buffer, } \\
\text { pH } 7 \cdot 2 \text {, in } 0.45 \mathrm{M} \\
\text { sodium chloride }\end{array}$ & $<1$ & $<1$ & $<1$ & $<1$ \\
\hline
\end{tabular}

*Antigen diluted 1/150.

tAntigen diluted 1/37.5.

\section{Other Fractionations}

Three sera were fractionated by gel filtration on Sephadex G-200. The first was from patient A.R. described above. The effluent diagram of this serum is depicted in Fig. 2. It is seen that the serological activity was, in accordance with the ultracentrifugal findings, mainly in the macroglobulin fraction. Some activity was also present in the intermediate fractions between the peaks of $\gamma \mathrm{M}$ and $\gamma \mathrm{G}$ globulin but none in the $7 \mathrm{~S}$ fraction. The intermediate fractions contained $\gamma \mathrm{A}$ globulin, but they also were found to contain considerable amounts of material reacting with the specific anti- $\gamma \mathbf{M}$ globulin serum. The gel filtration of this serum was repeated with similar results.

The second serum was from a person with transient reactions associated with small-pox vaccination. In this instance, the fractionation by gel-filtration confirmed the ultracentrifugal findings of the presence of serological activity solely in the macroglobulin fraction. 
The ultracentrifugal effluent diagram of the third serum was shown in Fig. 1b. The gel-filtration of this serum indicated that there was serological activity not only in the $7 \mathrm{~S}$ fraction but also in the intermediate fractions.

Fractionation experiments were then carried out with the aid of DEAE-cellulose column chromatography to characterize further the reactive substances. A step-wise elution system was employed. Table II summarizes some results obtained in these experiments. In three chronic BFP sera with the serological activity typically in the $7 \mathrm{~S}$ fraction, evidence was sought for the presence of activity associated with the $\gamma \mathrm{G}$ globulin. In each instance, the fall-through fraction obtained with $0.02 \mathrm{M}$ phosphate buffer, $\mathrm{pH} 7 \cdot 2$, contained some serological activity. The fractions were tested against whole human serum on Ouchterlony plates. Only one line was seen which gave a line of identity with the specific anti- $\gamma \mathrm{G}$ globulin serum.

In two chronic BFP sera and in two transient ones with the serological activity solely in the $19 \mathrm{~S}$ fraction, no activity was eluted with the above 0.02 $M$ phosphate buffer nor with this buffer in $0.15 \mathrm{M}$ sodium chloride. The sera had been mixed with equal volumes of a high-titred infectious mononucleosis serum. Neither did these fractions contain any mononucleosis agglutinins. In all sera the fractions obtained with the initial buffer in $0.3 \mathrm{M}$ sodium chloride contained the substances responsible for the BFP reactions, and these fractions also contained the mononucleosis agglutinins. No BFP activity, or only trace amounts of it, and no detectable mononucleosis agglutinins were eluted with the buffer in $0.45 \mathrm{M}$ sodium chloride.

The serum A.R. previously fractionated by gelfiltration was also fractionated with the above chromatographic system. In this instance, low titres were found in the fraction eluted with the phosphate-buffered $0.15 \mathrm{M}$ sodium chloride, although the main activity was eluted in the following step. Finally, in the case of serum P.P. previously shown in Fig. $1 b$, no activity was eluted from the column even with $0.45 \mathrm{M}$ sodium chloride.

\section{Immunization Experiments}

Two rabbits were immunized with VDRL floccules prepared from sera of two patients with BFP reactions (twelve intravenous injections over a 6 weeks' period). Immunoelectrophoresis and gel diffusion on Ouchterlony plates carried out against an infectious mononucleosis serum revealed the presence of antibodies only against immunoglobulins, but not against any other serum protein constituents.

\section{Discussion}

About a half of the BFP sera included in the study had serological reactions resembling those seen in syphilis, whereas the reactions of the remaining sera were atypical in some way. Observations made in the present work agree with the findings of Löffler (1959) that sera with transient BFP reactions associated with ornithosis do not react with cardiolipin antigens. The present study revealed another relatively common reaction pattern: sera completely negative in the VDRL test but fixing complement with Kolmer cardiolipin antigen, though they had an antigen optimum different from that of syphilitic sera. Some other sera reacted relatively weakly in the VDRL test and far better with crude alcoholic heart extracts and with the Kolmer antigen. It is possible that these sera contain a mixture of antibodies with different specificities: the major component reacts with the crude alcoholic heart extracts and with the Kolmer antigen but not with the VDRL antigen, and the minor component exhibits the syphilitic type of reaction pattern.

The ultracentrifugation experiments carried out in the present work showed that the serological activity was found solely in the $19 \mathrm{~S}$ fraction in 60 per cent. of the BFP sera. In fractionations with the aid of DEAE-cellulose chromatography, these $19 \mathrm{~S}$ substances were eluted in the same fractions with the $\gamma \mathrm{M}$ globulin, and rabbits immunized with VDRL floccules from such sera developed antibodies only against immunoglobulins. Thus there is hardly any doubt that the anti-lipoidal substances in these sera were antibodies of $\gamma \mathrm{M}$ globulin variety. In Part I of this paper it was seen that syphilitic anti-lipoidal antibodies were found only seldom in the $19 \mathrm{~S}$ fraction alone.

The majority of the syphilitic sera contained antibodies roughly in the same proportions in both $19 \mathrm{~S}$ and $7 \mathrm{~S}$ fractions. This type of activity distribution was found in four chronic BFP sera. Three of these sera were fractionated by DEAE-cellulose chromatography, and in each instance some serological activity was found in the fall-through fraction consisting of $\gamma \mathrm{G}$ globulin. In one case the patient had given birth to a baby with positive serological reactions. Since the $\gamma \mathrm{M}$ and $\gamma \mathrm{A}$ antibodies do not cross the placenta, this observation can be taken as further evidence of the $\gamma \mathrm{G}$ globulin nature of the reactive substances. All these four sera had serological reactions resembling those seen in syphilitic sera. Although there was no clinical or anamnestic evidence of syphilis in these patients and the sera had been repeatedly negative in the TPI and FTAABS tests, the possibility cannot be completely 
excluded that at least some of them may have had latent syphilis.

Some of the BFP sera had serological activity mainly in the $19 \mathrm{~S}$ fraction, with a relatively small component in the $7 \mathrm{~S}$ fraction. In one such serum the titres were very high, so that it was possible to further characterize the minor component. Recentrifugation experiments and gel-filtration on Sephadex G-200 revealed that it had intermediate sedimenting properties rather than those of $7 \mathrm{~S} \gamma \mathrm{G}$ globulin. A proportion of the syphilitic sera also had the majority of the antibodies in the $19 \mathrm{~S}$ fraction, with a minor component in the $7 \mathrm{~S}$ fraction. This was the situation with many of the high-titred sera from patients with late syphilis. However, the $7 \mathrm{~S}$ component in these sera was always composed at least in part of antibodies belonging to the $\gamma \mathrm{G}$ globulin fraction.

Two sera were found among transient BFP reactors in which the serological activity was roughly in the 7S fraction but appeared slightly before the peak of $\gamma \mathrm{G}$ globulin. No syphilitic sera were found with this type of activity distribution. One serum from a chronic BFP reactor had serological activity mainly in the $7 \mathrm{~S}$ fraction with a smaller component in the heavier fractions. The serologically active substances of this serum could not be eluted from DEAE-cellulose column even under conditions in which the $\gamma \mathrm{M}$ globulin antibodies are eluted.

It is possible that the serologically active substances in the BFP sera which did not belong to $\gamma \mathrm{M}$ or $\gamma \mathrm{G}$ globulins were antibodies of the $\gamma \mathrm{A}$ globulin variety. Some observations made on these substances were compatible with their $\gamma \mathrm{A}$ globulin nature. Thus, the $\gamma \mathrm{A}$ globulin antibodies occur in serum in monomeric form having a sedimentation coefficient of about $7 \mathrm{~S}$, and in dimeric or in trimeric form sedimenting in the fractions between the peaks of $\gamma \mathrm{M}$ and $\gamma \mathrm{G}$ globulin. However, there was no direct evidence of the association of anti-lipoidal activity with $\gamma \mathrm{A}$ globulin. There was some evidence of $\gamma \mathrm{A}$ globulin antibodies also in the syphilitic sera, and no definite conclusions can be drawn concerning possible differences in their occurrence in syphilitic and BFP sera.

Thus the most important difference in the distribution of the anti-lipoidal substances between the syphilitic and the BFP sera was the rare occurrence of antibodies of $\gamma \mathrm{G}$ globulin type in the BFP sera. This may be related to some differences in the mode of genesis of these substances. There is a certain parallelism with the anti- $\gamma$-globulin factors. Anti- $\gamma$-globulins induced by heteroimmunization (Coombs sera) belong, at least mainly, to $\gamma \mathrm{G}$ globulins. On the other hand, the autoantibody-type rheumatoid factors mainly are of $\gamma \mathrm{M}$ globulin variety, though rheumatoid factors of $\gamma \mathrm{G}$ and $\gamma \mathrm{A}$ variety have been described (Fudenberg, 1967).

\section{Summary}

Thirty sera from patients with various types of biological false positive sero-reactions for syphilis were fractionated by ultracentrifugation. 60 per cent. of he sera had the serologically active substances solely in the 19S fraction. Fractionations with the aid of DEAE-cellulose chromatography confirmed that the $19 \mathrm{~S}$ substances belonged to $\gamma \mathrm{M}$ globulins. Some sera from patients with persistent BFP reactions had the serologically active substances in about the same titres in the $\gamma \mathrm{M}$ and $\gamma \mathrm{G}$ globulin fractions. In five sera there was a major $19 \mathrm{~S}$ component and a minor component which in one instance was shown to be heavier than the $7 \mathrm{~S} \gamma \mathrm{G}$ globulin. Finally, three sera had the serologically active substances mainly or exclusively in the $7 \mathrm{~S}$ fraction. Half of the BFP sera included in the study had serological reactions resembling those seen in syphilis, whereas the remaining sera had atypical reaction patterns. Syphilitic type reactions prevailed in cases in which the distribution of serological activity in the serum fractions resembled that seen in syphilitic sera.

\section{REFERENCES}

Aho, K. (1967a). Brit. F. vener. Dis., 43, 259. (1967b). Int. Arch. Allergy, 31, 304.

Fudenberg, H. H. (1967). Clin. exp. Immunol., $2,1$. Lassus, A., Mustakallio, K. K., Aho, K., and Putkonen, T. (1967). Acta path. microbiol. scand., 69, 159.

Löffler, H. (1959). Schweiz. Z. allg. Path. Bakt., 22, 658.

Olansky, S., Harris, A., and Hill, J. H. (1953). Amer. F. Syph., 37, 23.

Salo, O. P., Somer, T., Aho, K., and Cantell, K. (1966). Ann. Med. exp. Fenn., 44, 304.

Salo, O., and Tuomioja, M. (1958). Ibid., 36, 223.

Tuffanelli, D. L., Wuepper, K. D., Bradford, L. L., and Wood, R. M. (1967). New Engl. F. Med., 276, 258.

Tuomioja, M., and Kajanne, P. (1956). Ann. Med. exp. Fenn., 34, 209.

\section{Études des anticorps syphilitiques}

II. Les substances responsables des séro-réactions biologiques pseudo-positives

\section{RÉSUMÉ}

Trente sérums obtenus de malades donnant des séro-reactions biologiques pseudo-positives (BPP) de types variés ont été fractionnés par l'ultracentrifugation. 60 pour cent des sérums avaient des substances sérologiquement actives seulement dans la fraction 19S. Les fractionnements faits avec l'aide de la chromatographie 
DEAE-cellulose ont confirmé que les substances $19 \mathrm{~S}$ appartenaient aux globulines $\gamma M$. Certains sérums des malades montrant une réaction BPP persistante avaient des substances sérologiques actives à peu près aux mêmes titres que celle des fractions des globulines $\gamma \mathrm{M}$ et $\gamma \mathrm{G}$. Dans cinq sérums il y avait un composant majeur $19 \mathrm{~S}$ et un composant mineur qui dans un cas a été demontré comme étant plus lourd que la globuline $7 \mathrm{~S} \gamma \mathrm{G}$. Finalement trois sérums avaient des substances séro- logiques actives principalement ou exclusivement dans la fraction 7S. La moitié des sérums donnant des réactions BPP inclus dans cette étude donnait des réactions sérologiques ressemblant à celles vues dans la syphilis, tandis que le reste des sérums donnait des réactions atypiques du même genre. Des réactions de type syphilitique ont prévalu dans les cas où la distribution de l'activité sérologique dans les fractions du sérum ressemblait à celle vue avec le sérum syphilitique. 